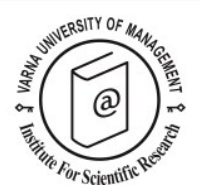

\title{
Functional Zoning for Smart Destination Management
}

\author{
Raúl Hernández-Martín ${ }^{1 *}$, Yurena Rodríguez-Rodríguez ${ }^{2}$ and Dominique Gahr ${ }^{2}$
}

\author{
Received: 29/10/2016 Accepted: 06/02/2017
}

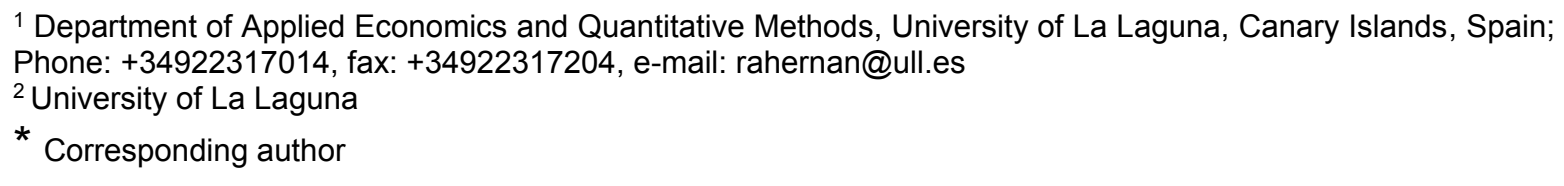

\begin{abstract}
Recent developments in destination management suggest that administrative divisions may be misleading as a unit of decision making for tourism planning and management, since they may comprise several areas with different tourism functionality. Identifying homogenous areas of tourism activity and delimiting their boundaries can enhance the utility of information for smart management purposes. The objective of this paper is to highlight the relevance of the geographical dimension of smart destinations by showing how functional areas can be delimited and how this smaller unit of analysis can improve destination management in the new context of improved availability of data and smart decisions supported by technology. The paper illustrates its key ideas with an application to the island of Gran Canaria.
\end{abstract}

(C) 2017 Varna University of Management. All rights reserved

Keywords: smart destinations, subdestinations, delimitation, destination management, Canary Islands.

Citation: Hernández-Martín, R., Y. Rodríguez-Rodríguez, and D. Gahr (2017) Functional Zoning for Smart Destination Management. European Journal of Tourism Research 17, pp. 43-58

\section{Introduction}

The current trend of combining information and communication technologies (ICTs) and human capital at destinations is expected to lead to an improvement in both the tourist experience and the tourist product within so-called smart destinations. In fact, it is this use of technology together with human capital in tourism that has led to the development of the concept of smart destination (Buhalis, Amaranggana, 2013).

Taking as a starting point the current concept of smart destinations (Gretzel et al., 2015; Boes et al. 2015), and recent literature on destination management (Beritelli, et al., 2014), this paper aims to make a contribution towards the operationalisation of the concept of smart destination, in particular, its geographical dimension. However, one of the challenges of this task lies in establishing agreed upon definitions of what the concepts smart and destination encompass, before being able to proceed with the practicalities of geolocation and data gathering for the spatial units that are subdestinations. As Gretzel et al. (2015) point out; smart tourism is related to the emerging forms of information and communication technologies that allow value to be obtained from large amounts of data. However, using these new forms of data to support decision 
making is not a straightforward process. Developing smart destinations must be linked to rethinking tourism destinations in order to provide sound support for decision making in tourism.

Promoting the information intensity and quality of decision making in tourism requires an increasing amount of recently available data to be structured. New types of information coming from devices or sensors are now more available for destinations. This information is often geolocated and can be displayed on maps and aggregated following different criteria. Nevertheless, local tourism area boundaries have not been clear enough. Delimitation of boundaries of destinations has not been a necessity in times when data related to administrative entities and intuition were behind the main tourism management decisions. However, the point of this paper is that management for smart tourism, which includes an intensive use of geolocated information, requires spatial units with tourism significance to be delimited as proposed by INRouTe and UNWTO (2012).

Recent developments in destination
management highlight the idea of disaggregating the destination into smaller functional areas. Beritelli et al. (2014) and Chapman \& Light (2016) consider the destination as an aggregation of different lifecycles at different stages. In fact, Beritelli et al. (2014) assume that the failure of destination management organisations (DMOs) is related to not taking into account the multiple and dynamic markets, actors and spaces within the area. Therefore, instead of a comprehensive view of the destination (Buhalis, 2000), the authors argue for a decomposition of them. Nevertheless, the aforementioned papers do not provide a clear methodology for establishing differentiated areas within destinations.

Despite the vast literature on tourism segmentation (Dolničar, 2004), little effort has been made for a functional geographic segmentation of destinations. The delimitation of smaller functional areas for management purposes within destinations, which have been called tourism districts (Pearce, 2001) or labelled as micro-destinations have been operationalised in the context of a public tourism statistical information system by Hernández-Martín et al. (2016). The increasing availability of data for decision-making can lead destinations to find themselves in an information maelstrom, the consequences of which are difficulties in processing data, especially data produced in real time. Having criteria for delimiting the geographical location of small homogeneous functional tourism areas can prove very useful to DMOs when it comes to generating new information for decision making. As such, this paper supports the usefulness of delimiting homogeneous subdestinations within wider tourism areas as a way of improving information utility and the quality of decision-making in the context of smart destinations. The underlying idea is that tourism areas usually contain several zones with different patterns of development, dates of construction, tourism products, demand segments, etc. and that it must be possible to differentiate these zones to optimise information supported management practices.

As Boes et al. (2015) highlight, the main element of smart destinations is human capital, which can promote leadership, innovation, entrepreneurship and social capital. Information technology infrastructures and applications are, in this context, enablers of this process. Therefore, smart destinations do not consist only in applying technological solutions but also in using and transferring existing knowledge for better decisions based on better information. The contribution of this paper is to show how the delimitation of functional areas with tourism relevance, subdestinations, can help to structure information and improve decisionmaking in the context of smart destinations.

The paper is organised as follows: after this introduction, section 2 discusses the concept of smart destination in the context of destination management. Smart destinations must be managed wisely as smartness is not only linked to technology and the firm level, but also to improving the quality of decision-making at the destination level. Section 3 discusses the concept of destination and the problem of identifying and delimiting destinations at a very local level, which proves particularly complex 
as the term destination encompasses different scales: a city, a municipality, a region, a country, a group of municipalities, an area of high tourist concentration, etc. Section 4 proposes a methodology for establishing geographical boundaries in tourism subdestinations and providing relevant information at this scale; while section 5 presents the results of an application in the Canary Islands (a consolidated tourism destination); section 6 discusses the results in the context of previous contributions, implications and extensions, while section 7 draws the conclusions.

\section{Smart destination management}

Smart destinations are an extension of the idea of smart cities applied to tourism areas. According to Lamsfus and Alzua-Sorzabal (2013:19) "a destination is a smart destination when the investments in human social capital and traditional transport and modern ICT communication infrastructure meet the social, cultural, economic, leisure and personal needs of visitors. Visitors are the short term citizens of a smart city". In addition, smart cities apply technological and energy solutions within the territory's management, working under the collaboration of citizens, public administrations and private enterprises (Manville et al., 2014).

The core idea behind smart destinations is that the use of technologies, particularly ICTs, can improve the ability of a destination to fulfil its own goals by providing quick and personalised responses to the needs of tourists, tourism firms and the government. Smart destinations represent a challenge for tourism destination management, as they hold great potential to support the development of destinations and their stakeholders. In fact, the way a destination is managed affects its competitiveness (UNWTO, 2007). Management of a smart destination needs to be integrated in order to achieve the manifold aims of a destination. The principal aims of a destination range from economic and social welfare to environmental efficiency and sustainability, competitiveness in comparison with other destinations, and improvement in the tourism experience as well as the quality of life of the local population (Buhalis, Amaranggana, 2013; Lamsfus, Alzua-Sorzabal, 2013). In fact, smart destinations allow for tourist experience personalisation (Buhalis, Amaranggana, 2015) and tourist experience co-creation, where tourists take an active role in developing a unique and personal experience, fostering destination competitiveness through interaction, participation and sharing (Buonincontri, Micera, 2016).

Despite several efforts, smart tourism remains poorly conceptualised (Werthner et al. 2015). Some authors highlight the driving role of technology, identifying smart tourism with the use of smart technologies (Gretzel et al., 2015), while others consider technology as an enabler, putting the focus on human capital and the process of making better decisions supported by ICT (Boes et al., 2015). This paper follows this second perspective that highlights governance, collective intelligence, and cooperation in tourism. In any case, ICT have triggered the possibilities for smart management of destinations. In this sense, the enabling role of ICT in the development of digital business ecosystems contributes to tight integration between digital and real components of tourism destinations (Baggio, Del Chiappa, 2014) that cannot be isolated in the analysis.

The technological background of smart destinations consists basically in the Internet of Things (IOT) amongst other advances related to the so-called big data. The loT (Atzori, et al., 2010) refers to a variety of non-living objects whose interaction is possible thanks to wireless communication systems. These systems include: sensors; tags; mobile phones and tablets; near-field communication (NFC); radiofrequency identification tags; and actuators located in the surroundings. These are sources of data, which enable the implantation of automated services by applying, for example, control mechanisms like access limitations (Wang et al., 2013). One of the most important advantages of big data is that it may demand relatively "low resources in terms of energy, storage, computing power, communication bandwidth capacity, heterogeneity (e.g., different objects, sensors, protocols and applications), dynamicity (e.g., arrival and departure of objects and sensors) and evolution" (Lamsfus et al., 2013:16). 
Collection of data, transmission, storage and subsequent analysis can make the difference, being the basis for a smart destination management. Manyika et al. (2011) show that big data refers to dataset sizes which are much more extensive than the usual databases. In a smart destination, stakeholders, residents, and tourists develop their own personal big lane of data whilst sharing content, communicating, searching for information, making reservations, shopping or even entertaining themselves. Big data can benefit private consumers thanks to the diverse number of end-user services. Enterprises can also gain in terms of competitiveness and productivity by using big data to enhance their value creation. Destinations need to find a way to transform big unstructured datasets into structured data that will allow for continuous analysis and effective decision-making (Davenport, 2013). However, the main point is not data compilation. For successful data exploitation, workers must be familiarised with the use of the statistical output. In fact, besides technology or hard smartness, smart destinations are strongly related to innovation, social and human capital and leadership (Boes et al., 2016; Errichiello, Marasco, 2017).

The main contribution of producing and processing information in tourism is value creation, which includes: providing a better picture of tourism demand and needs; allowing for more precise design and innovation; and facilitating more detailed decision-making. But it is not only the quantity of information that is important, but also its availability. As such, it is necessary to centralise and interconnect relevant data, linked data, and also to enable fast, free and open access, or open data. In this context, the concept of destination and the relevance of destination management organisations increase their central role. Information availability and management may improve competitiveness at the firm level. However, the smart destination can be a field for a broader application of this new approach in tourism. This application at destination level may change the organisations devoted to tourism management. This is in line with what Beritelli et al. (2014) identify as DMOs of the third generation.
Linked data enables consumers to easily navigate online information, whereas with open data everyone benefits from shared information, either by collecting data from other parties or, vice versa, by opening their databases to public use (see Larrinaga et al., 2013). Wang et al. (2013) consider cloud services to be a basic component of smart destinations. Cloud services include applications and software, among other media, that provide simplicity of access.

A smart destination is much more than a destination that applies technologies in an intensive way. The collaboration and cooperation of private and public stakeholders is a fundamental characteristic of a smart destination. This combination makes it possible to produce a large amount of data and information from different kinds of media. Cooperation among the diverse players enables a destination to be smart and work as a dynamic system, processing and analysing all the available information; all the users benefit from the enhanced information, including DMOs, private and public enterprises, tourists and even the local population. The relevance of stakeholder networking within a destination has been highlighted by Volgger \& Pechlaner (2014). More precisely, Del Chiappa \& Baggio (2015) used network analysis to study knowledge transfer in three Italian destinations. They found that the virtual component of a tourism destination is crucial for the efficient functioning of smart destinations and that the tight combination of real and virtual world in smart destinations facilitate the dissemination of knowledge.

The cross-sector feature of a smart destination and the diversity of players and users of its system represent a great challenge for destination management, one that requires ingenious and very sophisticated governance (Chourabi et al., 2012). To be successful, destination governance needs to encourage and manage these multiple interactions. That is why governance, in conjunction with highly qualified human resources is crucial to a smart destination (Errichiello, Micera, 2015). Whereas, on the one hand, sophisticated governance enables the development of a smart destination, on the other hand, a smart 
destination contributes to improving governance by providing tools that facilitate the coordination and exchange of information.

Smart destinations appear to be a great opportunity for tourism destination management, especially when it comes to cross-sector cooperation and long-term development. Nevertheless, it is necessary to pay attention to its multifactorial nature by embracing the diversity of stakeholders that compose a destination (Jamal, Jamrozy, 2006). This diversity implies a high degree of complexity when it comes to managing the system and coordinating the large numbers of stakeholders.

Despite the obvious importance of technology, smart should not just be measured in relation to the investment in technology. The notion of smart should be associated with the capacity to analyse data and apply the information obtained to implementing solutions within the destination, towards being more efficient, sustainable and competitive. This is in line with Sheehan et al. (2016) who consider a new role of DMOs as knowledge gatekeepers of the destination, which implies that the new main role of DMOs is knowledge management. In short, smart translates as being intelligent when it comes to decision making that improves the quality of life of residents and visitors. In addition, knowledge creation and transfer (Del Chiappa, Baggio, 2015; Errichiello, Marasco, 2017) within and between subdestinations must be a central aspect of smart tourism management. It is essential to point out that the ultimate goal should never be to create a smart destination for its own sake, instead it should be seen as a tool for reaching the objectives of a destination: better destination management, sustainability, a higher level of competitiveness, enhanced tourism experiences, and fostering the wellbeing of the local population, as shown by Manville et al. (2014) for smart cities.

\section{From tourism destinations to functional zoning (subdestinations)}

Tourism destination is one of the most important concepts in tourism research and, at the same time, one of the most difficult to define (Pearce, 2014). The complexity of destinations and the difficulties of their management have often been highlighted (Jamal, Jamrozy, 2006). As a result, researchers do not agree on how to operationalize this concept (Saraniemi, Kylänen, 2011). Some authors define it as a mere geographical area where visitors travel (Bull, 1994; Nadeau et al., 2008). Other papers focus the definition on tourism products supply; these authors define a tourism destination as the place where tourism resources are concentrated and products are generated to be consumed by tourists (Cooper et al., 2000; Gunn, 2002; Murphy et al., 2000). In this sense, Kim (1998) considers a destination a unique complex product that includes a particular climate, infrastructure and superstructure, services, and natural and cultural attributes. The World Tourism Organization (1998) distinguishes between tourism space, tourism town and tourism destination, considering the destination as the place where visitors consume the tourism product.

Other authors use the tourist experience to define the destination. For several of them, a tourism destination is a place that seeks to provide visitors with successful experiences by combining tourism products and services to attract them to the destination for tourism purposes (Bornhorst et al., 2010; Buhalis, 2000; Murphy et al., 2000).

By contrast, some researchers highlight the network nature of destinations. These authors consider that destinations are networks of connected organisations that represent the nodes within the tourism open system (Baggio, Cooper, 2010; Rodríguez-Díaz, EspinoRodríguez, 2008; Scott et al., 2008). In this approach, destinations can be seen as a form of cluster where firms compete and, at the same time, collaborate for their common interest (Bornhorst et al., 2010; Jackson, Murphy, 2006).

Finally, several papers define a destination taking into account the perceptions of tourists. Buhalis (2000) points out that a destination can be a perceptual concept, related to the subjectivity of the tourist; for one tourist the destination could be a city, for another it is the country and, even, for other tourists the 
destination could be the hotel, the cruise ship or certain renowned attractions (Bornhorst et al., 2010). That is to say, a destination could be defined at any scale, be it a whole country or region, a town or city, or even a local tourist attraction (UNWTO, 2007).

In short, tourism destinations have been defined in academic research as geographical areas, tourism products, tourism business networks, places where tourism experiences are provided, and as areas perceived by tourists as such. But a question remains, where are their boundaries? Buhalis (2000) complains that destinations can be artificially divided by geographical and political barriers, creating boundaries which fail to take into consideration the consumer perspective or the tourism industry functions. This last assertion is related to the topic of this paper: we cannot always use, without a loss of relevant information, official administrative boundaries to delimit a smart tourism destination.

In tourism related academic literature there are few references to the definition of tourism destination from a very local approach. In fact, relevant research related to destinations, such as Dwyer and Kim's model (2003), includes local conditions for resources or suppliers as a determinant of competitiveness, but the extent of which is considered local and the relationship with the concept of destination is neglected in the analysis. However, there is a bulk of literature on tourism destinations at the local scale. The UNWTO (2007) and Lew and McKercher (2006) use the concept of local destinations, while INRouTe \& UNWTO (2012) refer to them as tourism areas or micro local destinations. Dredge (1999) refers to this kind of small tourism area as a subdestination. By contrast, Hernández-Martín et al. (2016) labelled these areas as micro-destinations and Papatheodorou (2006) also uses the term micro-destination. However, in this case, it is not used in the very local approach; the example he provides for this concept is a business tourist travelling to Athens (Greece), the micro-destination being, in this case, the city of Athens.

Defining local destinations or subdestinations must not at all be associated with establishing them as independent agents with their own management strategies. As Ness et al. (2014) show, interdestination bridge ties promote a flow of information and knowledge transfer that may stimulate destination development. Likewise, Dredge (1999) highlights the synergies between tourism districts given that the competitiveness of the region is more than the sum of its tourism zones. Therefore, synergies must be promoted among subdestinations for mutual benefit. In addition, an extreme decentralisation of tourism management can be detrimental especially when the management scale is too small, as analysed by Yüksel et al. (2005).

There has been little attempt to map destinations (Pearce, 2014). Hernández-Martín et al., (2016) define micro-destinations as small geographical units highly dependent on tourism that comprise a wide range of tourism facilities and have a differentiated image and tourism typology. This new geographical area potentially provides a useful individual unit for the purposes of decision-making in smart tourism destination management and planning. What is more relevant, these authors provide guidelines for establishing the boundaries of this unit of analysis.

The concept smart has already been applied at different geographic scales, ranging from smart buildings to cities and regions, attractions, as well as islands (Pullen, 2013; Manville et al., 2014; Wang, 2016; Blanco-Sánchez, 2014). Smart cities, for example, refer to the administrative limits of the settlement, whereas smart islands include all the geographical extension of the land. Smart destinations can be attributed to limits in relation to the principal use of an area, for example, by tourists, being characterised by an elevated concentration of tourism infrastructures and a high share of tourism in the economic structure. The methodology for delimiting these so-called subdestinations is a useful approach to delimit the area embraced by a smart destination. The definition and application of this concept will be explained below.

In spite of the different size or scale of the area of destinations, the implications of what is called smart does not vary. Nevertheless, it 
may occur that some projects, which are included as basic elements to qualify as smart, cannot be implemented at every level of the scale, due to insufficient, too wide extension or lack of administrative competencies. Mitchell, who used the concept of smart city, most likely for the first time, stated that "we will encounter them at the scales of clothing, rooms, buildings, campuses and neighbourhoods, metropolitan regions, and global infrastructures" (Mitchell, 1999:68).

The geographic scale of smart destination projects is a controversial issue that must be faced. Given that synergies and complementarities in the early stages of implementation are very important, the application of this concept to relatively small areas and those with a concentration of tourists has different implications from its application in larger spaces with a lower concentration of tourism activity. This aspect has been highlighted by Pearce (2001) in the context of urban tourism. The author argues that setting tourism districts within a city plays a crucial role in analysing relevant patterns, processes, and interrelationships. Saraniemi and Kylänen, (2011) highlight that the shape, the content and the relationships in a destination may be interpreted completely differently by tourists, local people or tourism companies. Therefore, defining the boundaries of tourism districts or subdestinations must be oriented by the interest of the DMOs, given that their success is highly related to the success of the whole destination (Volgger, Pechlaner, 2014). Furthermore, Beritelli et al. (2014) also support this idea of decomposition of the destination for planning and development purposes into strategic business areas. The need for segmentation arises both in the case of urban tourism in traditional cities (as applied by Pearce, 1998, to the city of Paris) and in mass coastal tourism destinations (Hernández-Martín et al., 2016).

Reviewing the scientific literature on geographical delimitation, it is not easy to find examples of the identification of internally homogeneous areas in terms of certain characteristics, but heterogeneous with respect to the adjacent areas. This type of zoning has been carried out in fields such as sociology, public health, urban planning and geography by delimiting neighbourhoods according to certain research purposes. Neighbourhoods have been identified based on four main criteria: the first and most repeated is the subjectivity of local population and authorities (Coulton et al., 2001; Flowerdew et al., 2007; Sampson et al., 1997; Suttles, 1972); second, physical and social barriers (Cutchin et al., 2011; Flowerdew et al., 2007; Sampson et al., 1997; Suttles, 1972); third, enacted boundaries (Chaskin, 1997; Suttles, 1972); and, finally, homogeneity of the population or household characteristics (Flowerdew et al., 2007; Riva et al., 2008; Sampson et al., 1997; Spielman, Logan, 2012).

A subdestination can be considered "a spatial unit of statistical analysis characterised by a high density of establishments of tourism characteristic industries, homogeneous statistical tourism information, and a spatial continuity" (Hernández-Martín et al., 2016). Subdestinations may help to store, process and use the large amount of information that a tourism destination can currently collect in a more orderly way. It is thus, a very useful tool for arranging big data (Qiao et al., 2013) into geographically coherent areas.

\section{Methods}

In this paper, we use a tourism municipality in the south of Gran Canaria to analyse the use of tourism subdestinations as a tool to address smart destination management. This municipality is San Bartolomé de Tirajana, which contains the highest concentration of tourism supply in the Canary Islands, the region that has the highest figures for overnight stays in tourism accommodation in Europe (European Commission, 2015).

Despite defining boundaries of social entities being explicitly recognised as a hard task, in the literature on tourism destinations (Saraniemi, Kylänen, 2011) there is some research that can provide a starting point. In this paper, we follow the methodology developed by Hernández-Martín et al. (2016), who consider six criteria for delimiting tourism subdestinations: the concentration of establishments of tourism characteristic industries; the homogeneity of tourism typologies and tourism supply; the stability of 
boundaries over time; dynamism and flexibility; feasibility and relevance; and public and private support. The first criterion is applied to distinguish tourism areas from non-tourist areas. The second criterion is used to separate tourism areas in more than one subdestination, if necessary. The next three criteria provide the desirable characteristics of subdestinations to ensure the statistical utility and managerial relevance of these analytical areas. The last criterion is private and public support to the zonification by stakeholders. This criterion, also labelled as subjectivity, has obtained great support in other studies on grouping social entities (Coulton et al., 2001; Flowerdew et al., 2007; Sampson et al., 1997; Suttles, 1972) and has been a guidance during the process of delimitation of subdestinations.

These criteria were applied in a sequence supported by an expert consensus based in indicators between the research group, ISTAC and the DMO representatives in the Canary Islands. The two main criteria were concentration of tourism activity and homogeneity. The application of these criteria follows a supply side approach based on the characteristics of accommodation facilities. There are several advantages of using a supply side approach and accommodation establishments as the basis for zonification (Hernández-Martín et al., 2016). These advantages include: availability of data, given that information is compiled at the accommodation level elsewhere; stability, as supply side characteristics in a destinations do not change quickly over time; relevance, as accommodation accounts in most destinations for the most important segment of visitors; and representativeness, as tourism supply is correlated with demand segments, while the concentration of accommodation is often related to concentration of attractions and other tourist activities.

In the first phase, the criterion of concentration was applied and this allowed areas of high tourism concentration to be identified. The minimum threshold for concentration was established in 1,000 bed-places per square kilometre, the minimum number of bed-places in a subdestination was established in 1,000 and the minimum number of establishments within a destination was six, to guarantee confidentiality.

In a second phase, the criterion of homogeneity of tourism supply was applied. This criterion was applied by the expert panel through the use of a set of four indicators related to the characteristics of the supply of accommodation: age of the building, size of the accommodation establishment; category; and architectural model (number of plants). Once an initial zonification was obtained, the application of criteria three to five allowed refining the delimitation by checking for the stability of boundaries, allowing for the possibility of the evolution of subdestinations over time, as well as satisfying confidentiality issues and the analytical relevance of the areas delimited.

The geolocation of tourism accommodation establishments allowed the first aforementioned criterion to be applied: the concentration of tourism establishments. Areas of high concentration were separated from nontourism areas with low concentration of accommodation facilities. In addition, analysing the characteristics of these establishments made it possible to split up the area of high concentration of tourism accommodation establishments into homogeneous subdestinations in terms of the characteristics of the accommodation supply. In this application, the variables chosen to measure the homogeneity were age, type, category, quality, size and architectural model of accommodation establishments. Having identified the existing subdestinations within San Bartolomé de Tirajana municipal boundaries, the statistical data collected by the Canary Island Institute of Statistics was allocated geographically (see Hernández Martín et al., 2016).

The implementation of the criteria required a Geographic Information System (GIS) to be integrated within the System of Tourism Statistics (Singh et al., 2011). This system makes it possible to develop an inventory of all necessary alphanumeric information, to store it with geolocation, and to analyse it including the spatial dimension. 
Once the geolocation was performed, it was possible to link this data to statistical tourism information gathered by the Canary Islands Institute of Statistics and to geographically arrange the data gathered. ISTAC makes regular census surveys of all accommodation establishments in the archipelago. Furthermore, this statistical institute carries out surveys of a large sample of tourists (around 37,000 tourists every year) in the islands' airports at the time of their departure. In this survey, tourists are asked, among other questions, about the accommodation establishment where they stayed during their holidays and as such it is possible to geolocate a large amount of statistical tourism data from the supply-side (used in this research) and demand-side.

Statistical data from the accommodation survey in the Canary Islands was then georeferenced and aggregated in the resulting subdestinations. Online review data was obtained at the hotel level from a social media platform (Tripadvisor). The data were assigned and aggregated for each of the local destinations. More than 43.000 opinions were processed to obtain the results.

One of the main advantages of this methodology is its flexibility. This means that the boundaries of the areas can be changed over time and, accordingly, results can be easily recalculated for new areas. The use of new sources of information and the knowledge generated throughout the process can also provide feedback to change in the future the boundaries of the areas for different purposes.

\section{An application to the south of Gran Canaria (Canary Islands)}

Seven tourism subdestinations were identified by ISTAC within the municipality of San Bartolomé de Tirajana following the methodology developed by Hernández-Martín et al. (2016) (Figure 1). These seven subdestinations were (from West to East): Meloneras; Sonnerland; Campo Internacional; Playa del Inglés; El Veril - Las Burras; San Agustín; and Bahía Feliz - Playa el Águila. There were 368 accommodation establi-shments in the whole municipality in November 2015 following ISTAC figures.

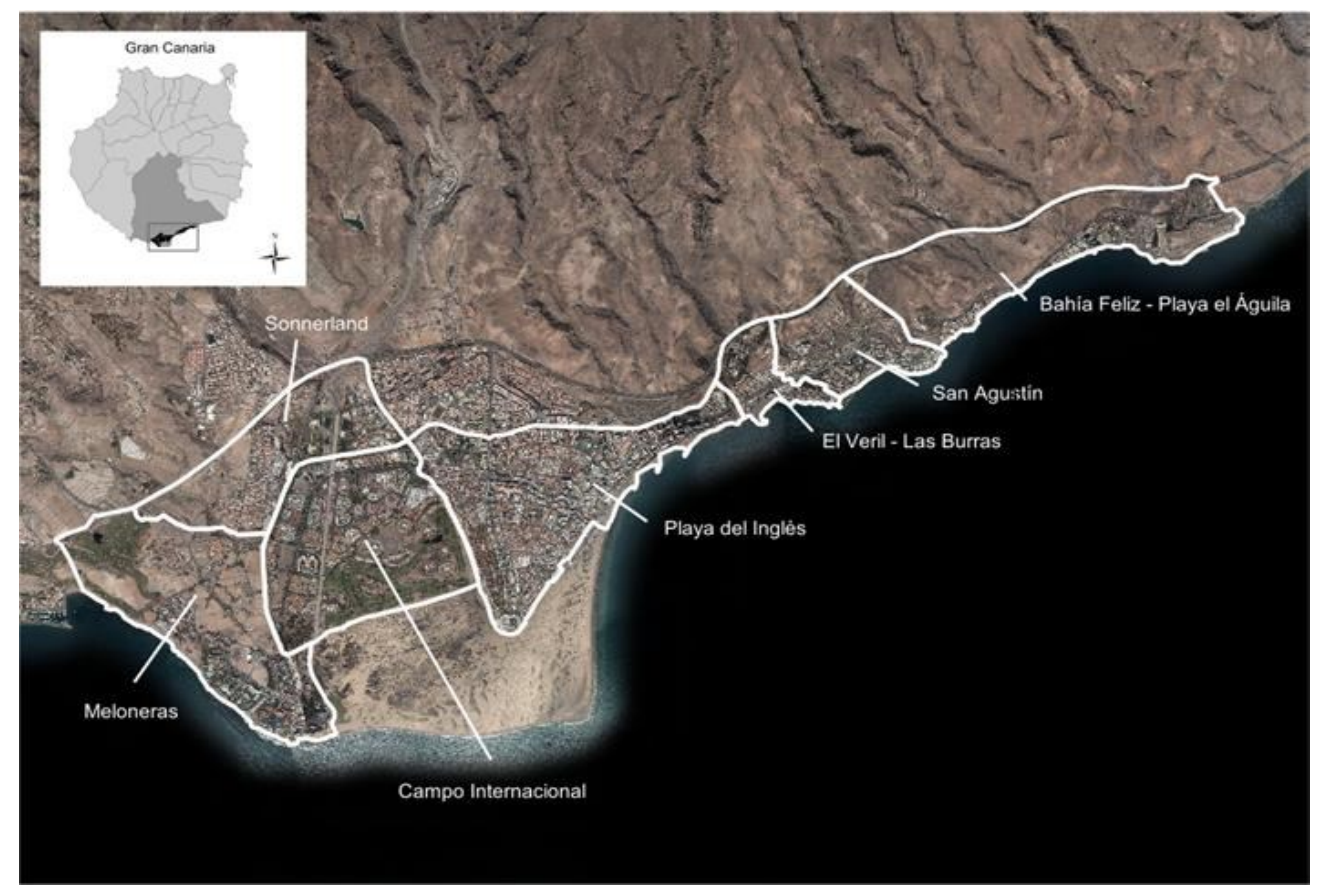

Figure 1. Tourism subdestinations in San Bartolomé de Tirajana (South of Gran Canaria) (ISTAC, subdestinations boundaries. GRAFCAN, aerial orthophotography and cartography) 
These seven small areas represent together about $1 \%$ of the island surface, and around $4.8 \%$ of the extension of the municipality. But despite occupying a relatively small area, they contain within their borders $69.5 \%$ of the island's bed-places. The statistical information obtained for these small geographical areas (Table 1) results in each of the seven subdestinations identified inside this municipality having a sufficient number of distinguishing features that justify producing specific tourism information for stakeholders (criteria 3, 4, 5 and 6).

In 2014, there were a total of 90,647 bedplaces in these seven subdestinations (ISTAC). These areas generated 18.4 million overnight stays in tourist establishments that year. This figure represents $69 \%$ of tourist overnight stays on the island. The number of overnight stays in each subdestination in 2014 went from about 328 thousands, to 9.7 million, according to ISTAC data.

Delimiting subdestinations allows the use of geolocated data from several sources to be integrated into a database to provide information on the dynamics of each tourist district, strategic business area or subdestination. Satisfaction with the accommodation is one of the most relevant items to consider in the competitiveness of a destination. The results from online reviews made on a social media platform show that in Meloneras, one subdestination of the municipality of San Bartolomé de Tirajana, the

Table 1. Tourism statistics for subdestinations. 2014

\begin{tabular}{|c|c|c|c|c|c|c|c|}
\hline Subdestination & $\begin{array}{l}\text { Arrivals in } \\
\text { tourism } \\
\text { accom. }\end{array}$ & $\begin{array}{l}\text { Overnights in } \\
\text { tourism } \\
\text { accommodation }\end{array}$ & $\begin{array}{l}\text { Average } \\
\text { length } \\
\text { of stay }\end{array}$ & $\begin{array}{c}\text { Rate of } \\
\text { occupan } \\
\text { cy }\end{array}$ & $\begin{array}{c}\text { Total daily } \\
\text { expenditure of } \\
\text { tourists }(2012)\end{array}$ & $\begin{array}{l}\text { Revenue } \\
\text { per } \\
\text { available } \\
\text { room }\end{array}$ & $\begin{array}{l}\text { Average } \\
\text { daily rate }\end{array}$ \\
\hline $\begin{array}{l}\text { Bahía Feliz- } \\
\text { Playa del } \\
\text { Águila }\end{array}$ & 90,428 & 748,350 & 8.28 & 51.4 & 122.75 & $54.88 €$ & $87.58 €$ \\
\hline $\begin{array}{l}\text { Campo } \\
\text { Internacional }\end{array}$ & 232,312 & $1,959,253$ & 8.43 & 48.02 & 124.40 & $38.18 €$ & $58.5 €$ \\
\hline $\begin{array}{l}\text { El Veril - Las } \\
\text { Burras }\end{array}$ & 37,599 & 328,929 & 8.75 & 44.02 & 150.59 & $45.49 €$ & $70.17 €$ \\
\hline Meloneras & 378,166 & $3,214,308$ & 8.50 & 84.26 & 171.29 & $119.89 €$ & $139.62 €$ \\
\hline Playa del Inglés & $1,096,691$ & $9,700,528$ & 8.85 & 52.56 & 128.42 & $43.18 €$ & $61.5 €$ \\
\hline San Agustín & 160,198 & $1,250,743$ & 7.81 & 57.52 & 127.87 & $67.04 €$ & $94.22 €$ \\
\hline Sonnerland & 146,360 & $1,236,226$ & 8.45 & 52.44 & 104.33 & $33.77 €$ & $50.47 €$ \\
\hline
\end{tabular}

Source: Canary Islands Institute of Statistics (ISTAC).

Table 2. Rating of hotels in a social media platform

\begin{tabular}{lrrrrrc}
\hline \multicolumn{1}{c}{ Subdestination } & Excellent & Very good & Normal & Bad & Very bad & TOTAL \\
\hline Bahía Feliz- Playa del Águila & $43.7 \%$ & $31.2 \%$ & $16.8 \%$ & $4.9 \%$ & $3.5 \%$ & $100.0 \%$ \\
Campo Internacional & $33.9 \%$ & $40.9 \%$ & $16.5 \%$ & $5.4 \%$ & $3.3 \%$ & $100.0 \%$ \\
El Veril - Las Burras & $50.2 \%$ & $34.8 \%$ & $9.9 \%$ & $3.6 \%$ & $1.6 \%$ & $100.0 \%$ \\
Meloneras & $59.2 \%$ & $28.1 \%$ & $8.0 \%$ & $2.8 \%$ & $2.0 \%$ & $100.0 \%$ \\
Playa del Inglés & $38.1 \%$ & $36.5 \%$ & $17.1 \%$ & $5.1 \%$ & $3.2 \%$ & $100.0 \%$ \\
San Agustín & $47.1 \%$ & $32.8 \%$ & $13.5 \%$ & $4.0 \%$ & $2.6 \%$ & $100.0 \%$ \\
Sonnerland & $23.8 \%$ & $39.8 \%$ & $22.7 \%$ & $7.8 \%$ & $5.8 \%$ & $100.0 \%$ \\
Average (municipality) & $\mathbf{4 5 . 0 \%}$ & $\mathbf{3 3 . 9} \%$ & $\mathbf{1 3 . 9} \%$ & $\mathbf{4 . 4} \%$ & $\mathbf{2 . 8} \%$ & $\mathbf{1 0 0 . 0} \%$ \\
\hline
\end{tabular}

Source: Data obtained 1 February 2015 from 43,166 online reviews in Tripadvisor. 
proportion of reviews with the rate of "excellent" was $52.2 \%$; by contrast, in the case of the subdestination of Sonnerland the rate of "excellent" accounted for hardly $23.8 \%$ of reviews. The differences in satisfaction among the subdestinations of the municipality of San Bartolomé de Tirajana shown in Table 2 strongly support the existence of a diversity of tourism zones, which require different interventions.

Results from online reviews of hotels can be combined with the official statistical data for Revenue per Available Room (RevPAR) in hotels (all categories) that is currently being published by ISTAC for these subdestinations. In Figure 2, it can be observed that there is a relationship between the satisfaction of tourists and the RevPAR of subdestinations. This information allows us to observe that the RevPAR of certain subdestinations (such as Meloneras) is more than three times that of others (such as Campo Internacional).

\section{Discussion}

The range of the values of indicators among the subdestinations in the south of Gran Canaria supports tourism policy instruments being adapted to the necessities of each local area. The differences observed in the satisfaction of tourists, daily rates and profitability, age of the buildings, etc. suggest different public or private interventions required. Some areas may require renovation of infrastructures; other areas may need marketing support, while other areas could suffer from congestion and pressures from tourist visits. In addition, zonification is a starting point to analyse tourism competitiveness at a very local level, tourism mobility, or tourism resources and points of interest (Lew, McKercher, 2006).

As mentioned above, smart destinations are not about technology. In fact, it is a way of enhancing tourism experiences through better information for decision making. In this sense, obtaining statistics at a subdestination level must be part of a broader goal such as developing a Regional Tourism Information System as proposed by INRouTe and UNWTO (2012). This kind of effort in tourism information can be fostered with new sources of information, big data and business intelligence. In fact, this process must be embedded in the building of a tourist digital business ecosystem (Baggio, Del Chiappa, 2014) and putting the focus on knowledge, governance and DMOs (Sheehan et al., 2016). In line with this proposal, Fuchs et al. (2014) use big data to develop a destination information system for the case of the region of Åre in Sweden. This information system is focused on business intelligence for tourism firm management.

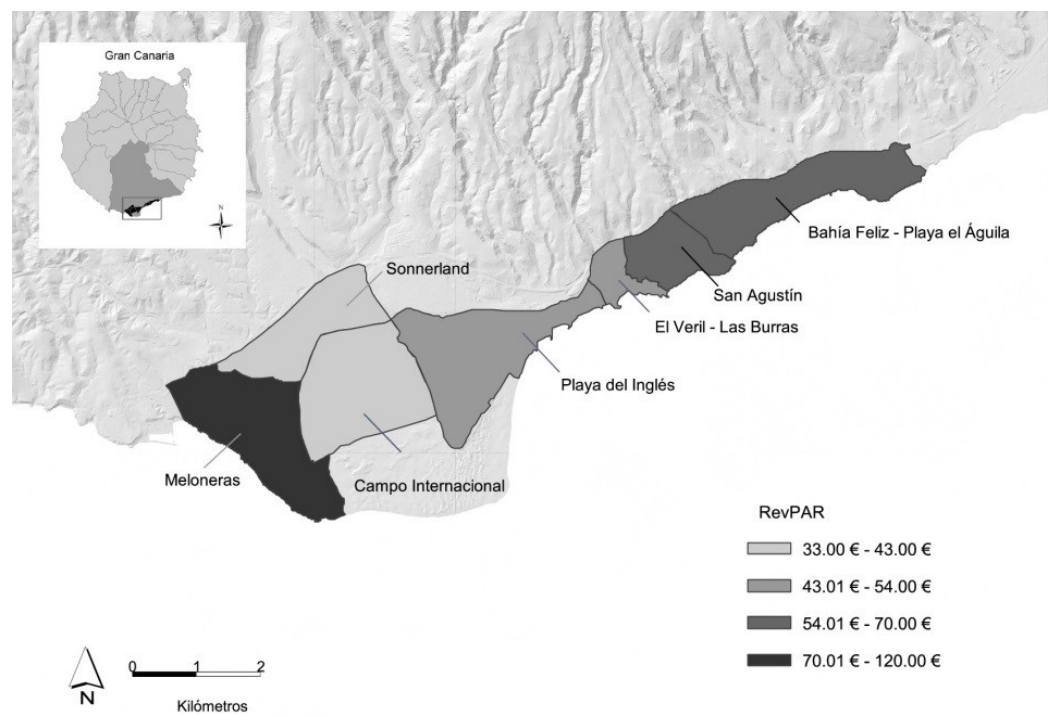

Figure 2. Revenue per Available Room (2014) (ISTAC) 
However, their application does not consider zonification of tourism areas.

Once official tourism statistics in the Canary Islands and some information provided by tourism social media are arranged, the next step in the development of the tourism information system could be to integrate other types of information, including big data, into these units of analysis. The geolocation of the information of the tourist expenditure survey will allow improving knowledge on tourism behaviour. Furthermore, the Internet is generating a great number of datasets that are too complex to work with using traditional database management tools (Yiu, 2012). With regards to this point, subdestinations could help in the process of analysing big datasets to derive insights of value for decision-making in tourism destinations. Linking big data to small functional geographical units could simplify this process and provide relevant information. Therefore, it could be feasible to establish at a subdestination level: the evaluation that tourists have of collective accommodation establishments (as already done); the type of web searches they do; the use of online travel agencies and destination webs; tourist mobility within and between subdestinations; mobile phone calls and tracking; energy consumption; environmental indicators; payments with credit cards; and other relevant aspects from administrative records, such as the generation of waste or the tax burden for each of these small analytical areas.

The research included in this paper is part of a body of research using new sources of data that are currently contributing to the smart management of destinations. Marine-Roig and Anton-Clavé (2015) analyse an exhaustive dataset of user generated content consisting of more than 100,000 travel blogs and online reviews, for the city of Barcelona, to obtain useful information to improve destination marketing. However, this kind of analysis should be improved taking into account the distribution of tourists in the destination using the place of accommodation or the sites they visit. In this case, zonification would be a way of creating valuable information for smart decisions, given the uneven concentration of tourism activities within destinations. Another relevant contribution in this field uses geographical information systems to improve the tourist experience (Supak et al., 2015). The authors exploit data from reservations in National Parks in the USA to display the geographical origin of consumers linked to other characteristics, as a new way of using information for smart tourism management. In this case the interest is not related to the behaviour or satisfaction of tourists in the destination but with the characteristics of tourists and the places of origin using ZIP codes.

The methods and the application presented in this paper may have to be adapted in case of being applied to other destinations. The nature of destinations and the interest of decision makers can result in different ways of organising geographically the destination for knowledge development and information management. What is being emphasised here is the potential contribution of an ex-ante delimitation of homogeneous local tourism destinations for smart destination management. In any case, the results presented above can be adapted to the necessities of other destinations. It is worth noting that subdestinations can be designed at different levels of disaggregation and, can even overlap each other's' boundaries (Beritelli et al. 2014).

\section{Conclusion}

Destination management can be supported by the features associated with smart destinations. In particular, the increased production of data related to the activity of tourists, devices and stakeholders in tourism can serve as the raw material for improved management practices. Nevertheless, transforming data into useful information for real-time, real-life decisionmaking is not a straightforward process and requires a global approach to the development of smart destinations.

Tourism activity tends to be concentrated in or near historical sites, beaches, national parks, attractions, etc. In order to make tourism information more useful, there is a need to define tourism areas that are homogeneous, with their own identity and relevance, which can be the targets of tourism policies and planning. This is particularly relevant when the 
possibility of gaining access to, rearranging and using information for decision making is improved by technology. In this paper, we have applied a methodology developed in the context of organising traditional tourism statistical data to establish the boundaries of tourism zones. We have provided useful insights on how tourism management and planning of smart destinations can be improved with the information obtained by processing data for functional areas with the help of zonification, since the whole destination may contain different zones with different tourism functionality.

The south of Gran Canaria provides a good example of a tourism area containing several internally homogeneous subdestinations, though differentiated among them. Official statistical data for these subdestinations are markedly different from each other and the information provided by online hotel reviews has also showed that treating the area as homogenous is not adequate. In addition, the information that may be available in the future from big data compiled from telecom firms, banks, social networks, sensors, transport, smartphones or online travel agencies may be allocated to subdestinations to provide guidelines for decision making. In the case of accommodation ratings in social media platforms, the figures show marked differences among these subdestinations, thus supporting the hypothesis of different characteristics of the areas and the relevance and utility of producing and using different information to make decisions at this scale.

If we consider organising all the information geographically in the form of subdestinations, we take the first step towards improving the utility of information that can then be used to enhance tourists' experiences and facilitate interaction and integration between the tourist and the destination. The result then is that identifying and using subdestinations can contribute to the development and management of smart destinations and increasing tourism competitiveness. Furthermore, the data collected in the subdestinations when converted into useful information for decision-making can be a source of information to change the boundaries of these areas.

Despite the fact that the delimitation of subdestinations in this paper has been based on existing knowledge and even subjective aspects, obtaining new data will provide a source of information for a more accurate and useful delimitation of boundaries in the future using clustering techniques. The boundaries of subdestinations should not be perceived as static and unchangeable. However, it must be recognised that continuous changes in the boundaries of subdestinations could limit the usefulness of the information obtained.

The case of Gran Canaria must be seen as an example, given that the scale or size of tourism areas in other regions or countries should be adapted to the characteristics of tourism activity and the necessities of tourism boards. The main contribution of this paper is to demonstrate that delimiting tourism zones (subdestinations) can prove useful for the purposes of establishing smart destinations and for the purposes of DMOs. This is a way to operationalize and obtain useful information at a level which is higher than the firm level but lower than the municipality or regional level.

\section{References}

Atzori, L., lera, A., \& Morabito, G. (2010). The Internet of Things: A survey. Computer Networks, 54(15), 2787-2805.

Baggio, R., \& Cooper, C. (2010). Knowledge transfer in a tourism destination: The effects of a network structure. The Service Industries Journal, 30(10), 1757 - 1771.

Baggio, R., \& Del Chiappa, G. (2014). Real and virtual relationships in tourism digital ecosystems. Information Technology \& Tourism, 14(1), 3-19.

Beritelli, P., Bieger, T., \& Laesser, C. (2014). The new frontiers of destination management. Journal of Travel Research, 53(4), 403-417.

Blanco-Sánchez, A. (2014). Sustainability in the Global Tourism Industry: Good Practice Initiatives from the Private and Public Sector. EI Hierro 100\% Renewable Energies. In R. Egger \& C. Maurer (Eds.), ISCONTOUR 2014 -Tourism Research 
Perspectives (203-211). Norderstedt: Herstellung und Verlag.

Boes, K., Buhalis, D., \& Inversini, A. (2015) Conceptualising Smart Tourism Destination Dimensions. In: Tussyadiah I, Inversini A, (eds.): Information and Communication Technologies in Tourism 2015. (pp. 391-403). Springer International Publishing

Boes, K., Buhalis, D., \& Inversini, A. (2016) Smart tourism destinations: ecosystems for tourism destination competitiveness. International Journal of Tourism Cities, 2(2), 108-124.

Bornhorst, T., Ritchie, J. R., \& Sheehan, L. (2010). Determinants of tourism success for DMOs \& destinations: An empirical examination of stakeholders' perspectives. Tourism Management, 31(5), 572 - 589.

Buhalis, D. (2000). Marketing the competitive destination of the future. Tourism Management, 21(1), $97-116$.

Buhalis, D., \& Amaranggana, A. (2013). Smart Tourism Destinations. In Z. Xiang \& I. Tussyadiah (Eds.), Information and Communication Technologies in Tourism 2014, (pp. 553-564). Springer, Cham

Buhalis D., Amaranggana A. (2015). Smart Tourism Destinations Enhancing Tourism Experience through Personalisation of Services. In: Tussyadiah I. \& Inversini A. (eds) Information and Communication Technologies in Tourism 2015. (pp. 377390).Springer, Cham,

Bull, A. (1994). The economics of travel and tourism. Melbourne: Pitman.

Buonincontri, P., \& Micera, R. (2016). The experience co-creation in smart tourism destinations: a multiple case analysis of European destinations. Information Technology \& Tourism, 16(3), 285-315.

Chapman, A. \& Light, D. (2016). Exploring the tourist destination as a mosaic: The alternative lifecycles of the seaside amusement arcade sector in Britain. Tourism Management, 52, 254-263.

Chaskin, R. J. (1997). Perspectives on neighborhood and community: A review of the literature. Social Service Review, 71(4), 521-547.

Chourabi, H., Nam, T., Gil-Garcia, J.R; Mellouni, S., Nahon, K., Pardo, T., \& Scholl, H.J. (2012). Understanding Smart
Cities: An Integrative Framework. IEEE Computer Society, $45^{\text {th }}$ Hawail International Conference on System Sciences, 2289-2297.

Cooper, C., Fletcher, J., Gilbert, D., \& Wanhill, S. (2000) Tourism: Principles and practice (2nd edn.). Harlow: Longman.

Coulton, C. J., Korbin, J., Chan, T., \& Su, M. (2001). Mapping Residents' Perceptions of Neighborhood Boundaries: A Methodological Note. American Journal of Community Psychology 29(2), 371-383.

Cutchin, M. P., Eschbach, K., Mair, C. A., Ju, H. \& Goodwin, J.S. (2011). The sociospatial neighborhood estimation method: An approach to operationalizing the neighbourhood concept. Health \& Place, 17(5), 1113-1121.

Davenport, T. (2013). At the big data crossroads: turning towards a smarter travel experience. Amadeus IT Group, Madrid.

Del Chiappa, G., \& Baggio, R., (2015). Knowledge transfer in smart tourism destinations: Analyzing the effects of a network structure. Journal of Destination Marketing \& Management, 4(3), 145-150.

Dolničar, S. (2004). Beyond "commonsense segmentation": A systematics of segmentation approaches in tourism. Journal of Travel Research, 42(3), 244-250.

Dwyer, L. \& Kim, C. (2003). Destination Competitiveness: Determinants and Indicators. Current Issues in Tourism, 6(5), 369-414.

Dredge, D. (1999). Destination place planning and design. Annals of Tourism Research, 26(4), 772-791.

Errichiello, L., \& Marasco, A. (2017). Tourism Innovation-Oriented Public-Private Partnerships for Smart Destination Development. In Scott, N., De Martino, M., Van Niekerk M. (Eds.) Knowledge Transfer to and within Tourism, (pp.147 166). Emerald Publishing,

Errichiello L., \& Micera R. (2015). Smart Tourism Destination Governance. In Spender, J.S., Shiuma, G., \& Albino, V. (Eds.) Culture, Innovation and Entrepreneurship: connecting the knowledge dots, (pp. 2179-2191). Proceedings of IFKAD 2015 - International 
Forum on Knowledge Asset Dynamics, 10-12 June, Bari.

European Commission (2015). Eurostat regional yearbook 2015. Luxembourg.

Flowerdew, R., Feng, Z., \& Manley, D. (2007). Constructing data zones for Scottish Neighbourhood Statistics. Computers, Environment and Urban Systems, 31(1), 76-90.

Fuchs, M., Höpken, W., \& Lexhagen, M. (2014). Big data analytics for knowledge generation in tourism destinations - a case from Sweden. Journal of Destination Marketing \& Management, 3(4), 198-209.

Gretzel, U., Sigala, M., Xiang, Z. \& Koo, C. (2015). Smart tourism: foundations and developments. Electronic Markets, 25(3), 179-188.

Gretzel, U., Werthner, H., Koo, C. \& Lamsfus, C. (2015). Conceptual foundations for understanding smart tourism ecosystems. Computers in Human Behavior 50, 558563.

Gunn, C. (2002) Tourism planning: Basics, concepts, cases (4th edn.). New York, NY: Taylor \& Francis.

Hernández-Martín, R., Simancas-Cruz, M. R., González- Yanes, J. A., RodríguezRodríguez, Y., García-Cruz, J. R. \& González-Mora, Y. M. (2016). Identifying micro-destinations and providing statistical information: a pilot study in the Canary Islands. Current Issues in Tourism, 19(8), 771-790.

International Network on Regional Economics, Mobility and Tourism \& United Nations World Tourism Organization (2012). A closer look at tourism: Sub-national measurement and analysis- towards a set of UNWTO guidelines. Madrid: UNWTO.

Jackson, J., \& Murphy, P. (2006). Clusters in regional tourism - an Australian case. Annals of Tourism Research, 33(4), 1018 $-1035$.

Jamal, T., \& Jamrozy, U. (2006) Collaborative networks and partnerships for integrated destination management. In Buhalis \& Costa (Eds.): Tourism management dynamics. Trends, management and tools. Elsevier, Amsterdam, 164-172.

Kim, H. (1998). Perceived attractiveness of Korea destinations. Annals of Tourism Research, 25(2), 340 - 361.
Lamsfus, C., \& Alzua-Sorzabal, A. (2013). Theoretical Framework for a Tourism Internet of Things: Smart Destinations. Tourgune, Journal of Tourism and Human Mobility 0, 15-21.

Larrinaga, F., Lizarralde, O., Serna, A., \& Gerrikagoitia, J. K. (2013). Caso de uso de "Open Data" y "Linked Data" en Turismo. Tourgune, Journal of Tourism and Human Mobility, 0, 31-39.

Lew, A. \& McKercher, B. (2006), Modeling tourist movements: A local destination analysis. Annals of Tourism Research. 33(2), $403-423$.

Manville, C., Cochrane, G., Cave, J., Millard, J., Pederson, J.K., Thaarup, R.K., Liebe, A., Wissner, M., Massink, R., \& Kotternik, B. (2014). Mapping Smart Cities in the EU. European Parliament, Brussels.

Manyika, J., Chui, M., Brown, B., Bughin, J., Dobbs, R., Roxburgh, C. \& Byers, A.H. (2011). Big data: The next frontier for innovation, competition, and productivity. McKinsey Global Institute.

Marine-Roig, E. \& Anton Clavé, S. (2015). Tourism analytics with massive usergenerated content: A case study of Barcelona. Journal of Destination Marketing \& Management, 4(3), 162-172.

Mitchell, W.J. (1999). E-topia: "Urban Life, JimBut Not As We Know It". Massachusetts: First MIT Press.

Murphy, P., Pritchard, M. P., \& Smith, B. (2000). The destination product and its impact on traveller perceptions. Tourism Management, 21(1), 43- 52.

Nadeau, J., Heslop, L., O'Reilly, N. \& Luk, P. (2008) Destination in a country image context. Annals of Tourism Research, 35(1), 84-106.

Ness, H., Aarstad, J., Haugland, S. A., Grønseth, B. O. (2014). Destination development: The role of interdestination bridge ties. Journal of Travel Research, 53(2), 183-195.

Organización Mundial del Turismo (1998): Introducción al turismo. Madrid: Organización Mundial del Turismo.

Papatheodorou, A. (2006). Microfoundations of tourism choice. In L. Dwyer \& P. Forsyth (ed.), International handbook on the economics of tourism. Cheltenham: Edward Elgar, 73 - 88. 
Pearce, D. G. (1999). Tourism in Paris. Studies at the microscale. Annals of Tourism Research, 26(1), 77-97.

Pearce, D. G. (2001). An integrative framework for urban tourism research. Annals of Tourism Research, 28(4), 926-946.

Pearce, D. G. (2014). Toward an integrative conceptual framework of destinations. Journal of Travel Research, 53 (2), 141153.

Pullen, D. (2013). Smart buildings researchfocus for the future. Paper presented at the meeting of the Parliamentary and Scientific Committee on Smart Buildings, London, United Kingdom.

Qiao, X., Zhang, L., Li, N. \& Zhu, W. (2013). Constructing a Data Warehouse Based Decision Support Platform for China Tourism Industry. In Z. Xiang \& I. Tussyadiah (Eds.), Information and Communication Technologies in Tourism 2014. New York: Springer. 883-893.

Riva, M., Apparicio, P., Gauvin, L. \& Brodeur, J. M. (2008) Establishing the soundness of administrative spatial units for operationalizing the active living potential of residential environments: An exemplar for designning optimal zones. International Journal of Health Geographics, 7(1), 43-56.

Rodríguez-Díaz, M. \& Espino-Rodríguez, T. F. (2008) A model of strategic evaluation of a tourism destination based on internal and relational capabilities. Journal of Travel Research, 46(4), 368 - 380.

Saraniemi, S., \& Kylänen, M. (2011). Problematizing the Concept of Tourism Destination: An Analysis of Different Theoretical Approaches. Journal of Travel Research 50 (2), 133-143.

Sampson, R. J., Raudenbush, S. W., \& Earls, F. (1997). Neighborhoods and violent crime: A multilevel study of collective efficacy. Science, 277(5328), 918-924.

Scott, N., Cooper, C. \& Baggio, R. (2008). Destination networks: Four Australian cases. Annals of Tourism Research, 35(1), 169 - 188.

Sheehan, L., Vargas-Sánchez, A., Presenza, A., \& Abbate, T. (2016). The use of intelligence in tourism destination management: An emerging role for DMOs. International Journal of Tourism Research, 18(6), 549-557.
Singh, S. P., Sharma, J., \& Singh, P. (2011). A geo-referenced information system for tourism (GeoRIST). International Journal of Geomatics and Geosciences, 2(2), 456 -464 .

Spielman, S. E., \& Logan, J. R. (2012). Using high-resolution population data to identify neighborhoods and establish their boundaries. Annals of the Association of American Geographers, 103(1), 67-84.

Supak, S., Brothers, G., Bohnenstiehl, D., \& Devine, H. (2015). Geospatial analytics for federally managed tourism destinations and their demand markets. Journal of Destination Marketing \& Management, 4(3), 173-186.

Suttles, G. D. (1972). The social construction of communities. Chicago, IL: University of Chicago Press.

United Nations World Tourism Organization (2007). A practical guide to tourism destination management. Madrid: UNWTO.

Volgger, M., \& Pechlaner, H. (2014). Requirements for destination management organizations in destination governance: Understanding DMO success. Tourism Management, 41, 64-75.

Wang, D., Li, X., \& Li, Y. (2013). China's "smart tourism destination" initiative: A taste of the service-dominant logic. Journal of Destination Marketing \& Management, 2(2), 59-61.

Wang, X., Li, X. R., Zhen, F., \& Zhang, J. (2016). How smart is your tourist attraction? Measuring tourist preferences of smart tourism attractions via a FCEMAHP and IPA approach. Tourism Management, 54, 309-320.

Werthner, H., Koo, C., Gretzel, U., \& Lamsfus, C. (2015). Special issue on smart tourism systems: Convergence of information technologies, business models, and experiences. Computers in Human Behavior, 50, 556-557.

Yiu, C. (2012). The big data opportunity: Making government faster and more personal. London: Policy Exchange.

Yüksel, F., Bramwell, B., Yüksel, A. (2005). Centralized and decentralized tourism governance in Turkey. Annals of Tourism Research, 32(4), 859-886. 